San Jose State University

SJSU ScholarWorks

Master's Theses

Master's Theses and Graduate Research

Fall 2012

\title{
Microsatellite and mitochondrial DNA analysis of Dungeness crab (Cancer magister) from California to northern British Columbia
}

Bryan Thomas Barney

San Jose State University

Follow this and additional works at: https://scholarworks.sjsu.edu/etd_theses

\section{Recommended Citation}

Barney, Bryan Thomas, "Microsatellite and mitochondrial DNA analysis of Dungeness crab (Cancer magister) from California to northern British Columbia" (2012). Master's Theses. 4222.

DOI: https://doi.org/10.31979/etd.nwc5-6rfx

https://scholarworks.sjsu.edu/etd_theses/4222

This Thesis is brought to you for free and open access by the Master's Theses and Graduate Research at SJSU ScholarWorks. It has been accepted for inclusion in Master's Theses by an authorized administrator of SJSU ScholarWorks. For more information, please contact scholarworks@sjsu.edu. 


\title{
MICROSATELLITE AND MITOCHONDRIAL DNA ANALYSIS OF DUNGENESS CRAB (CANCER MAGISTER) FROM CALIFORNIA TO NORTHERN BRITISH COLUMBIA
}

\author{
A Thesis \\ Presented to \\ the Faculty of the Department of Biological Sciences \\ San José State University \\ In Partial Fulfillment \\ of the Requirements for the Degree \\ Master of Science
}

by

Bryan Thomas Barney

December 2012 
(C) 2012

Bryan Thomas Barney

ALL RIGHTS RESERVED 
The Designated Thesis Committee Approves the Thesis Titled

\section{MICROSATELLITE AND MITOCHONDRIAL DNA ANALYSIS OF DUNGENESS CRAB (CANCER MAGISTER) FROM CALIFORNIA TO NORTHERN BRITISH COLUMBIA}

by

Bryan Thomas Barney

APPROVED FOR THE DEPARTMENT OF BIOLOGICAL SCIENCES

SAN JOSÉ STATE UNIVERSITY

December 2012

Dr. Leslee Parr Department of Biological Sciences

Dr. Joshua Mackie Department of Biological Sciences

Dr. Brandon White Department of Biological Sciences 


\begin{abstract}
MICROSATELLITE AND MITOCHONDRIAL DNA ANALYSIS OF DUNGENESS

CRAB (CANCER MAGISTER) FROM CALIFORNIA TO NORTHERN BRITISH

COLUMBIA
\end{abstract}

by

Bryan Thomas Barney

Genetic variation was assessed using mitochondrial DNA and microsatellite markers from Dungeness crab between Iceberg Bay, British Columbia and San Luis Obispo, California. We found little pattern in overall genetic variation between sites in both marker types, and no significant Isolation by Distance model was fit. Site-specific variation in mitochondrial DNA haplotype frequencies suggested the existence of three subpopulations associated with the Alaska Current, the Puget Sound, and the California Current, but microsatellite DNA evidence did not support it. The ratio between sampling size for microsatellite markers and fragment size polymorphisms was low, limiting the resolving power of microsatellite DNA for neutral variation. Average pairwise $F_{s t}$ values for Iceberg Bay, British Columbia against all other populations was 0.156 , as compared to the average pairwise $F_{s t}$ of 0.028 across all populations. In the southern region of the Puget Sound, Nisqually, Washington had a lower pairwise $F_{s t}$ of 0.044 but contained a large number of site-specific, unique mtDNA haplotypes. Additionally, we found 41 mtDNA haplotypes in 445 samples taken, with 23 of those haplotypes as "singletons," suggesting that Dungeness crab went through a recent, post-bottleneck population expansion, likely associated with the most recent glacial relaxation. 


\section{Acknowledgements}

Before I thank anyone else, I need to give the largest possible helping of gratitude to Lisa (my wife) and Linnea (my daughter). The patience they had with me and the completion of this phase of our lives was herculean in nature and without them I would never have been where I am today. There is no way that a few words here could express my feelings - I thank you both from the very bottom of my heart. In addition, I cannot imagine I would be where I am today without the guidance and love of my parents, Thomas and Patricia Barney. I owe my late father an immeasurable amount for my lifelong habit of stopping, stooping, and staring at every pool of water I pass by, and my mother has been an amazing support for me in both times of joy and pain.

I would like to thank my thesis committee, Drs. Leslee Parr, Josh Mackie, and Brandon White, for their copious patience with me and this project. My time at San Jose State University was highly enriched by each one of you in turn, and I look forward to future potential collaborations!!

Also, I would like to thank the numerous collaborators for THIS project who provided samples for DNA extraction, which both allowed this study to have a much larger breadth of the ecological range of Dungeness crab and personally saved me the effort of hauling crab-trapping gear all across the Pacific seaboard! Dr. Graham Gillespie provided samples from British Columbia crab, Mitch Vance provided legs from Oregon crab, and Corinne Lardy provided previously sequenced data from California samples. In particular, Don Velasquez from the Washington State Department of Fish and Wildlife 
was instrumental in coordinating the effort of sampling across the Puget Sound area. This involved both providing samples from an existing female reproductive success study, allowing me to sit in on one of the sampling trips, and getting me in touch with Native American tribal biologists for areas outside of their study: Kelly Toy, from the Jamestown S'Klallam tribe, and Paul Williams, of the Suquamish tribe. All were instrumental in getting this complicated coordination effort to happen smoothly and with little to no delay.

Lastly, I would like to thank San Jose State University and the Biology Department for their support. Financial support for this work was provided by the Arthur and Karen Nelson Research Fellowship, the Arthur and Karen Nelson Scholarship, and the Robert Hyde Scholarship. 


\section{TABLE OF CONTENTS}

$\underline{\text { Subject }}$

$\underline{\text { Page }}$

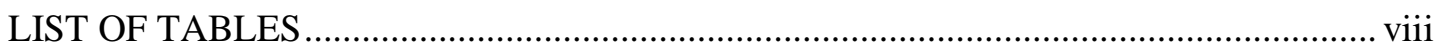

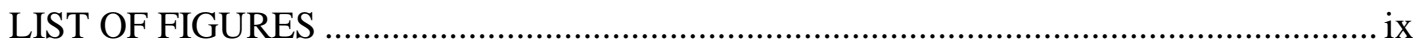

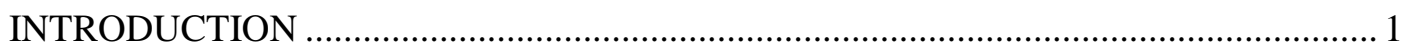



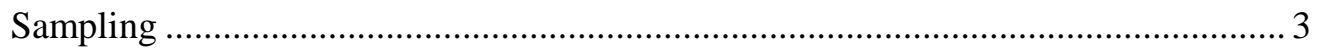

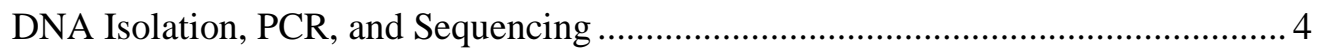

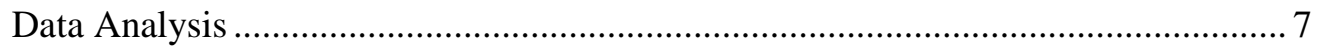

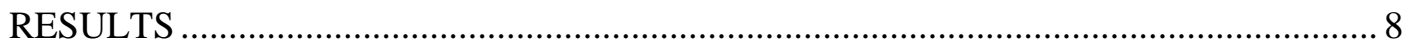

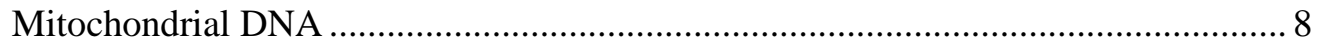

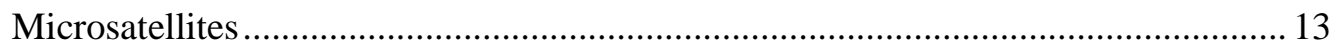

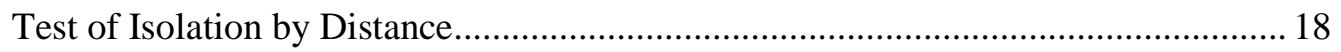

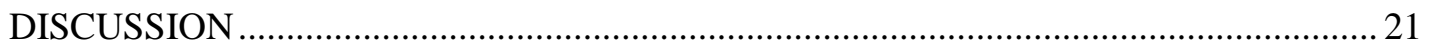

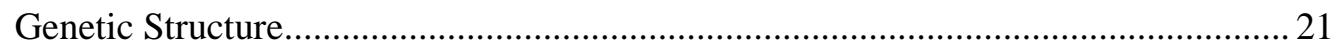

Population Expansion after a Bottleneck ….......................................................... 24

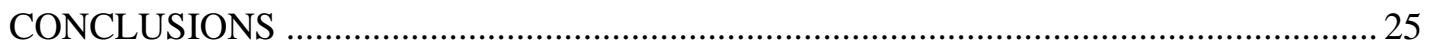

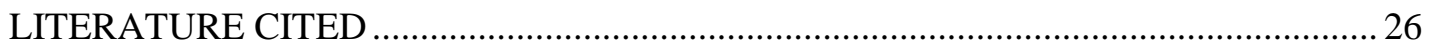




\section{LIST OF TABLES}

$\underline{\text { Table }} \quad \underline{\text { Page }}$

1 - Primer sequences and annealing temperatures used for PCR amplifications.......6

2 - Summary of mtDNA sequence variability.............................................

3 - Pairwise $F_{s t}$ values for mtDNA COI sequences............................................ 14

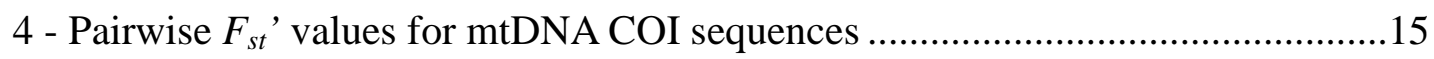

5 - Pairwise Jost's $D$ values for mtDNA COI sequences ..................................... 16

6 - Summary statistics for all microsatellite loci ............................................. 17

7 - Average $R h o_{s t}$ for each locus at each sampling location.................................. 18

8 - Pairwise $R h o_{s t}$ and Jost's $D$ for all microsatellites combined ............................20 


\section{LIST OF FIGURES}

$\underline{\text { Figure }} \quad \underline{\text { Page }}$

1 - Sampling locations used in this study......................................................4

2 - Haplotype network of mtDNA sequences ...................................................... 10

3 - COI mtDNA frequencies for each sampled site .......................................... 12 


\section{$\underline{\text { Introduction }}$}

The Dungeness crab (Cancer magister, Dana 1852) is a decapod crustacean found along the North American Pacific shore in bays and estuaries from the Aleutian Islands in Alaska southward to Point Conception, California. It is a heavily fished species, characterized by wide fluctuations in yearly landings. The fishery is managed by multiple state and federal agencies through seasonal fishing periods, limited permitting, male-only fishing, and age limits by minimum carapace size. None of the current management methods include the assessment of connectivity of the fished populations and assume that populations in heavily fished areas will be replenished by continued recruitment of new juveniles from nearby, less-fished regions.

For $C$. magister, larvae are the primary means of long-range dispersal, as adults typically operate in a home range between $1 \mathrm{~km}^{2}$ and $10 \mathrm{~km}^{2}$ (Stone \& O'Clair 2001). C. magister larvae have a typical development period of 3-4 months, depending on water temperature (Poole 1966, Wild 1983). During development, C. magister larvae grow through five zoeal stages and one megalops phase prior to metamorphosing to a benthic juvenile crab (Wild 1983). It is within these larval phases that primary dispersal happens, and the long pelagic larval duration gives the propagules a high dispersal potential (Palumbi 2003, Shanks et al. 2003, but see Weersing \& Toonen 2009). Larvae are released seasonally by females between December and April, with southern populations typically releasing eggs in the earlier months and northern crab releasing eggs in the later months (Cleaver 1949, Butler 1956, Lough 1976, Wild 1983). Larvae released earlier likely travel northward along the Davidson current which is at the surface from 
December to late February or early March (Huyer et al. 1989). As the Davidson current relaxes and is replaced by the California current sometime in late February to March, those larvae released later in the season are likely to be transported southward by the California current. This potential for the traversal of larvae in either direction likely leads to genetic connectivity through gene flow between subpopulations, but understanding the magnitude of the spatial scale at which there is cohesive dispersal is challenging (Wing et al. 1995, Sponaugle et al. 2002).

Direct measurement of oceanic larval dispersal remains a technological challenge, so indirect measures, such as estimation of gene flow through genetic inference, are heavily relied upon (See reviews in Cowen \& Sponaugle 2009, Hellberg 2009, Selkoe \& Toonen 2011). Several studies have investigated the potential dispersal distances and barriers to dispersal of marine organisms using genetic information (Kelly \& Palumbi 2010, Galindo et al. 2010, Pinsky et al. 2010), but little has been done to investigate gene flow and population connectivity in Cancer magister. Early electrophoretic investigation showed little variation (Soule \& Tasto 1983). Since then, several sets of microsatellites have been isolated (Toonen et al. 2003, Jensen \& Bentzen 2004, Kaukinen et al. 2004) for use in population differentiation investigation, but they were utilized in only one study within British Columbia (Beacham et al. 2008), where little evidence of genetic structure was found. This is unsurprising, as differences between subpopulations should be negligible when there is a high amount of gene-flow between subpopulations through migration (Slatkin 1973, Galindo et al. 2010). There are, however, examples where DNA evidence has been used to discover sharp genetic breaks in otherwise continuous 
populations of other marine invertebrates (Reeb \& Avise 1990, Sotka et al. 2004). In addition, there is the potential for localized larval retention and recruitment, leading to smaller dispersal scales even in marine species with long pelagic larval duration (Taylor \& Hellberg 2003).

The objective of this study was to investigate the genetic connectivity of Dungeness crab between central California and northern British Columbia using both mitochondrial DNA and nuclear markers (microsatellites). We sampled adult Dungeness crab across $\sim 2500 \mathrm{~km}$ of the Pacific coastline to test for signals of population substructure and limitations to gene flow across the ecological range. We were additionally interested to see if there is genetic evidence of larval retention within Puget Sound, as there is recruitment-based evidence of this phenomenon (Dinnel et al. 1993, Mcmillan et al. 1995).

\section{Methods}

Sampling

Between June and September 2009, 20-25 adult crabs were sampled at 14 sampling locations (Figure 1) using either recreational ring-nets or commercial crab pots. Non-lethal sampling consisted of removal of the right fifth walking leg at the coxa. Oregon samples were collected in coordination with the Oregon Department of Fish and Wildlife. British Columbia samples were collected in coordination with Fisheries and Oceans Canada. Anacortes, Ilwaco, and Grays Harbor samples were collected by the author. All other samples were collected in coordination with the Washington 
Department of Fish and Wildlife or Native American tribal biologists, depending on the management agency appropriate to the specific sampling location. Samples were frozen (on dry ice in the field, at $-20^{\circ} \mathrm{C}$ in the lab) until tissue extraction. DNA sequences from California samples (listed as CAEU, CASF, CASL in Figure 1) collected in 2005 (Lardy 2005) were included to give greater breadth of ecological range coverage to the sample set.
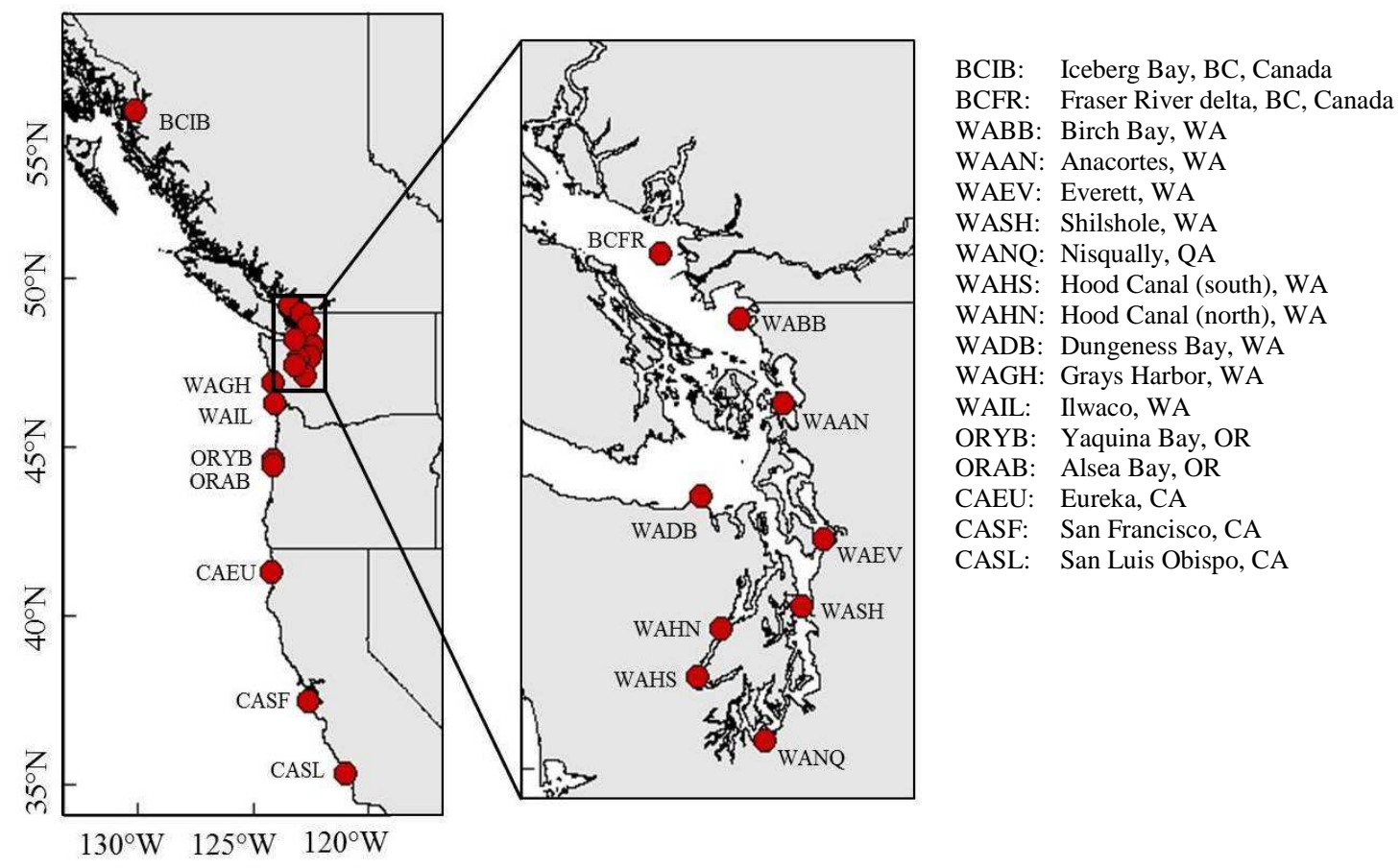

Figure 1: Sampling locations used in this study. Sampling sites are indicated by dots on the map above. Between 20 and 25 samples were collected at each site between June and September 2009. California samples (CAEU, CASF, and CASL) were collected in 2005 (Lardy 2005)

\section{DNA Isolation, PCR, and Sequencing}

Muscle tissue was removed from beneath the carapace of the largest proximal segment of the right fifth walking leg and total DNA was isolated using the Qiagen 
DNEasy® Blood and Tissue Kit. DNA extractions were checked for quality via agarose gel electrophoresis, and quantity was measured using a NanoDrop® ND-1000 spectrophotometer prior to use in PCR.

A 302-bp fragment of the cytochrome c oxidase subunit I (COI) mitochondrial gene was amplified in a $50 \mu \mathrm{l}$ PCR reaction which consisted of 1-20 ng total DNA, 1x PCR buffer (10 mM Tris- $\mathrm{HCl}\left(\mathrm{pH} 8.8\right.$ at $\left.25^{\circ} \mathrm{C}\right), 2.5 \mathrm{mM} \mathrm{MgCl}_{2}, 50 \mathrm{mM} \mathrm{KCl}, 0.1 \%$ Triton® X-100), 1 unit of DyNAzyme ${ }^{\mathrm{TM}}$ II DNA polymerase (Finnzymes), $0.2 \mathrm{mM}$ dNTPs, $0.4 \mathrm{mM}$ of each primer (see Table 1 for primer sequences), and $0.4 \mathrm{mg} / \mathrm{ml}$ bovine serum albumin. Thermocycler conditions consisted of an initial denaturation step at $94^{\circ} \mathrm{C}$ for $5 \mathrm{~min}$, followed by 35 cycles consisting of denaturation at $94^{\circ} \mathrm{C}$ for $30 \mathrm{~s}$, annealing at $50^{\circ} \mathrm{C}$ for $45 \mathrm{~s}$, and extension at $72^{\circ} \mathrm{C}$ for $60 \mathrm{~s}$. On completion, a final extension at $72^{\circ} \mathrm{C}$ for 5 min was performed. PCR products were purified using the Qiagen QIAquick® PCR Purification Kit according to manufacturer's instructions and sequenced using the forward primer at either Geneway Research (Hayward, CA) or Sequetech (Mountain View, CA). Reverse sequencing was performed on $10 \%$ of the samples, including samples with ambiguous sequencing results, to ensure the validity of sequence calls from forward sequencing.

Microsatellites were amplified using only the first 10 individuals from each site sampled (BCIB through ORAB, no California samples were available for amplification). Seven microsatellite loci were amplified in $15 \mathrm{ml}$ PCR reactions which consisted of 1-20 ng total DNA, 1x Qiagen Multiplex PCR Master Mix (includes PCR buffer, 6 mM $\mathrm{MgCl}_{2}, \mathrm{dNTPs}$, and HotStarTaq ${ }^{\circledR}$ polymerase), 1x Qiagen Q-solution, $0.2 \mathrm{mM}$ of each 
primer (Table 1 for sequences), and $0.4 \mathrm{mg} / \mathrm{ml} \mathrm{BSA}$. Thermocycler conditions consisted of an initial denaturation step at $95^{\circ} \mathrm{C}$ for 15 min, followed by 40 cycles consisting of denaturation at $94^{\circ} \mathrm{C}$ for $30 \mathrm{~s}$, annealing at the primer-specific temperature (Table 1) for $60 \mathrm{~s}$, and extension at $72^{\circ} \mathrm{C}$ for $60 \mathrm{~s}$. On completion, a final extension at $60^{\circ} \mathrm{C}$ for 30 minutes was performed.

Table 1: Primer sequences, 5' modifications, and annealing temperatures used for all PCR amplifications in this study.

\begin{tabular}{|c|c|c|c|c|}
\hline Primer & Sequence $\left(5^{\prime}-3^{\prime}\right)$ & 5' Tag? & $\begin{array}{c}\text { Anneal } \\
\text { Temp (C) }\end{array}$ & $\begin{array}{c}\text { Primer } \\
\text { Reference }\end{array}$ \\
\hline COI - Forward & GGAGGATTTGGAAATTGATT & $\mathrm{n} / \mathrm{a}$ & \multirow{2}{*}{50} & \multirow{2}{*}{$\begin{array}{c}\text { (Harrison \& } \\
\text { Crespi 1999) }\end{array}$} \\
\hline COI - Reverse & GTACAGGAAGGGATAGTAGT & & & \\
\hline Cma102 - Forward & TTCAGCTGCACTTCAGTGAT & 6-FAM & \multirow{2}{*}{52} & \multirow{2}{*}{$\begin{array}{c}\text { (Kaukinen et al. } \\
\text { 2004) }\end{array}$} \\
\hline Cma102 - Reverse & CTGTAGTGAACTAAATTACTGTT & & & \\
\hline Cma103 - Forward & GTTCCAAATACAGTTGACC & NED & \multirow{2}{*}{52} & \multirow{2}{*}{$\begin{array}{c}\text { (Kaukinen et al. } \\
\text { 2004) }\end{array}$} \\
\hline Cma103 - Reverse & GTCTTCCTATGTCCTCCTT & & & \\
\hline Cma108a - Forward & GCAGTAGGAACAGCAGCTGAT & HEX & \multirow{2}{*}{52} & \multirow{2}{*}{$\begin{array}{c}\text { (Kaukinen et al. } \\
\text { 2004) }\end{array}$} \\
\hline Cma108a - Reverse & GTTTATTTCGTCACCAGAGAGA & & & \\
\hline Cma108b - Forward & CAGGTGTGGTTGTGTCCCTTTA & HEX & \multirow{2}{*}{54} & \multirow{2}{*}{$\begin{array}{l}\text { (Kaukinen et al. } \\
\text { 2004) }\end{array}$} \\
\hline Cma108b - Reverse & GTTCAGTTGAACCCAGAGTGACA & & & \\
\hline Cma114 - Forward & CAAGTAAGAGAATGGAATCGTATT & 6-FAM & \multirow{2}{*}{52} & \multirow{2}{*}{$\begin{array}{c}\text { (Kaukinen et al. } \\
\text { 2004) }\end{array}$} \\
\hline Cma114 - Reverse & GTTTGCCAAAGAGCATCAGTGACAA & & & \\
\hline Cma117 - Forward & GTCTGAGACGAGCCAACATC & NED & \multirow{2}{*}{52} & \multirow{2}{*}{$\begin{array}{c}\text { (Kaukinen et al. } \\
\text { 2004) }\end{array}$} \\
\hline Cma117 - Reverse & GTTTCAACAGGAAACATGAAATAGGAT & & & \\
\hline Cma118 - Forward & GGAGAGGGAGCGACTGTC & NED & \multirow{2}{*}{54} & \multirow{2}{*}{$\begin{array}{c}\text { (Kaukinen et al. } \\
\text { 2004) }\end{array}$} \\
\hline Cma118 - Reverse & GTTTGGTGTATTACAAAACAACCAGTAA & & & \\
\hline
\end{tabular}

Microsatellite fragment size analysis was performed on an ABI 3100 Genetic Analyzer (Applied Biosystems Inc., Foster City, CA) at the Genomics/Transcriptomics Analysis Core facility at San Francisco State University. Fragment sizes were determined using GeneScan Analysis Software v3.1 (Applied Biosystems Inc., Foster City, CA). California samples (CAEU, CASF, CASL) were not analyzed in this fashion as the template DNA was unavailable. 


\section{Data Analysis}

All nucleotide base calls from mtDNA sequence trace files were visually confirmed prior to analysis. Sequences were aligned using MEGA version 5.05 (Tamura et al. 2011). A haplotype network for COI sequence haplotypes was constructed using ARLEQUIN version 3.5.1.2 (Excoffier \& Lischer 2010) and the minimum spanning tree algorithm (Rohlf 1973). Pairwise $F_{s t}$ differences (as $\theta$ ) between sampling sites were calculated (Weir \& Cockerham 1984) using FSTAT version 2.9.3 (Goudet 2001). Following Hedrick (Hedrick 2005), pairwise $F_{s t}$ ' (or “ $F_{s t}$ prime”) differences were also calculated in FSTAT by first transforming haplotype information to site-specific unique haplotype names using recodeData (Meirmans 2006), then dividing the observed pairwise $F_{s t}$ values by the theoretical maximums obtained after haplotype transformation. Pairwise Jost's D (Jost 2008) was determined using GenoDive version 2.0b21(Meirmans \& Van Tienderen 2004). For all pairwise comparison sets $\left(F_{s t}, F_{s t}\right.$, and Jost's $\left.D\right)$, Spearman rank coefficient tests were performed using GenePop version 4.1.0 (Rousset 2008), and Mantel tests were performed using FSTAT in order to test the fit to an isolation by distance model. Tajima's $D$ (Tajima 1989), Fu's Fs (Fu 1997), and Fu and Li's $F^{*}$ and $D^{*}(\mathrm{Fu} \& \mathrm{Li} 1993)$ were calculated using DnaSP version 5.10.01 (Librado \& Rozas 2009)

For microsatellites, Exact Tests for departure from Hardy-Weinberg equilibrium (using the Markov chain method), linkage disequilibrium, and pairwise $R h o_{s t}$ differences for each microsatellite locus were calculated using GenePop as were pairwise $R$ ho $_{s t}$ 
differences for the 7 loci combined. Pairwise Jost's $D$ was determined for all loci combined using GenoDive. For all mtDNA and microsatellites combined, Spearman rank coefficient tests were performed using GenePop, and partial Mantel tests for isolation by distance were performed using FSTAT to test the fit to an isolation by distance model.

\section{$\underline{\text { Results }}$}

\section{Mitochondrial DNA}

A total of 445 mtDNA COI sequences generated were collapsed down to 41 unique haplotypes. Of the 41 haplotypes found, 23 (or $56 \%$ of all haplotypes) were "singletons" found in only one individual within the entire population. Nearly all (37 of $41, \sim 90 \%$ ) of the 41 haplotypes sequenced (including the major haplotypes 1,2 , and 3 ) coded for the same amino acid sequence within the $302 \mathrm{bp}$ sequenced range. Summary statistics for mtDNA variation within each sampling site and for the overall sampled population are shown in Table 2. In general, there was relatively low nucleotide diversity $(\pi)$, ranging from $0.15 \%$ to $0.53 \%$ and an overall population diversity of $0.37 \%$. The transition to transversion ratio (as $R$ ) was 24.2 , showing a very high bias towards transition mutations. Haplotype diversity was relatively high, ranging from 0.6 to 0.8 in most sampled locations due to the presence of a large number of low-frequency sitespecific haplotypes. The highest haplotype diversity $(h=0.835)$ was found in Nisqually, Washington (WANQ), at the southern end of the Puget Sound. Haplotype diversity was much lower $(h=0.30)$ in Iceberg Bay, British Columbia (BCIB), as this location was 
dominated by haplotype 1 individuals. The large number of low-frequency haplotypes throughout the sampled population was reflected in the strongly negative score for both Fu's $F s$ and Tajima's $D$.

Table 2: Summary of mtDNA sequence variability from Dungeness crab sampled in 2005 and 2009. $n$ : number of samples from site; $\pi$. nucleotide diversity; $k$ : avg. number of nucleotide differences; \#haplo: number of haplotypes at site; $h$ : haplotype diversity. For Fu's $F s, \mathrm{Fu}$ and Li's $F^{*}$ and $D^{*}$, and Tajima's $D$, statistically significant results are shown in bold with asterisk $(\mathrm{s})(*=\mathrm{p}<0.05 ; * *=\mathrm{p}<0.01)$.

\begin{tabular}{|c|c|c|c|c|c|c|c|c|c|}
\hline Sample & $\boldsymbol{n}$ & $\boldsymbol{\pi}$ & $\boldsymbol{k}$ & \# haplo. & $\boldsymbol{h}$ & $\mathbf{F u} \mathbf{F} \boldsymbol{F}$ & $\begin{array}{c}\text { Fu \& Li } \\
\boldsymbol{F} *\end{array}$ & $\begin{array}{c}\text { Fu \& Li } \\
\boldsymbol{D}^{*}\end{array}$ & $\begin{array}{c}\text { Tajima's } \\
\boldsymbol{D}\end{array}$ \\
\hline BICB & 25 & 0.00150 & 0.453 & 5 & 0.300 & -2.992 & -0.515 & -0.203 & -1.158 \\
\hline BCFR & 25 & 0.00371 & 1.120 & 8 & 0.630 & -3.902 & $\mathbf{- 3 . 0 9 0} *$ & $\mathbf{- 3 . 0 4 9} *$ & $\mathbf{- 2 . 1 5 8} *$ \\
\hline WABB & 21 & 0.00413 & 1.248 & 8 & 0.719 & -3.897 & -1.936 & -1.876 & $\mathbf{- 1 . 9 8 1} *$ \\
\hline WAAN & 24 & 0.00425 & 1.283 & 8 & 0.732 & -3.431 & -2.087 & -1.903 & $\mathbf{- 1 . 9 4 0} *$ \\
\hline WAEV & 25 & 0.00272 & 0.820 & 5 & 0.657 & -1.355 & -0.142 & -0.203 & -1.158 \\
\hline WASH & 24 & 0.00402 & 1.214 & 7 & 0.783 & -2.460 & -1.050 & -0.973 & -1.514 \\
\hline WANQ & 22 & 0.00526 & 1.589 & 6 & 0.835 & -0.754 & -0.709 & -0.635 & -1.102 \\
\hline WAHN & 25 & 0.00371 & 1.120 & 7 & 0.760 & -2.664 & -1.731 & -1.741 & $\mathbf{- 1 . 8 8 6} *$ \\
\hline WAHS & 21 & 0.00271 & 0.819 & 4 & 0.586 & -0.414 & -0.133 & -0.142 & -1.164 \\
\hline WADB & 19 & 0.00387 & 1.170 & 6 & 0.602 & -1.878 & -1.015 & -0.822 & -1.62 \\
\hline WAGH & 24 & 0.00464 & 1.402 & 6 & 0.761 & -0.973 & -2.479 & -2.449 & $\mathbf{- 2 . 1 5 9 *}$ \\
\hline WAIL & 25 & 0.00419 & 1.267 & 8 & 0.797 & -3.383 & -0.918 & -0.711 & -1.682 \\
\hline ORYB & 25 & 0.00413 & 1.247 & 7 & 0.727 & -2.290 & -2.022 & -2.042 & $\mathbf{- 1 . 8 8 6} *$ \\
\hline ORAB & 21 & 0.00375 & 1.133 & 6 & 0.752 & -1.802 & -1.215 & -1.247 & -1.727 \\
\hline CAEU & 37 & 0.00320 & 0.967 & 6 & 0.709 & -1.482 & -0.747 & -0.702 & -1.564 \\
\hline CASF & 52 & 0.00275 & 0.831 & 8 & 0.630 & -3.735 & -1.974 & -1.899 & -1.748 \\
\hline CASL & 30 & 0.00430 & 1.299 & 10 & 0.800 & -5.367 & -2.467 & -2.363 & $\mathbf{- 2 . 0 0 8 *}$ \\
\hline OVERALL & 445 & 0.00369 & 1.113 & 41 & 0.708 & $\mathbf{- 5 1 . 2 9 1} * *$ & $\mathbf{- 3 . 7 8 0} *$ & $\mathbf{- 3 . 9 5 1} *$ & $\mathbf{- 2 . 3 2 1} * *$ \\
\hline
\end{tabular}

A haplotype network was constructed from the 41 sequence haplotypes using the minimum spanning network output from ARELQUIN (Figure 2). The morphology of the network reveals a "star phylogeny" of mtDNA sequence haplotypes centered on the three most frequent sequences, haplotypes 1,2, and 3 in decreasing frequencies. This is in 
agreement with the highly negative Fu's $F s$ and Tajima's $D$ scores, indicating that there may be either recent population expansion driving the generation of novel, low-frequency haplotypes through mutation, or positive selection increasing the relative frequency of the selected haplotypes.

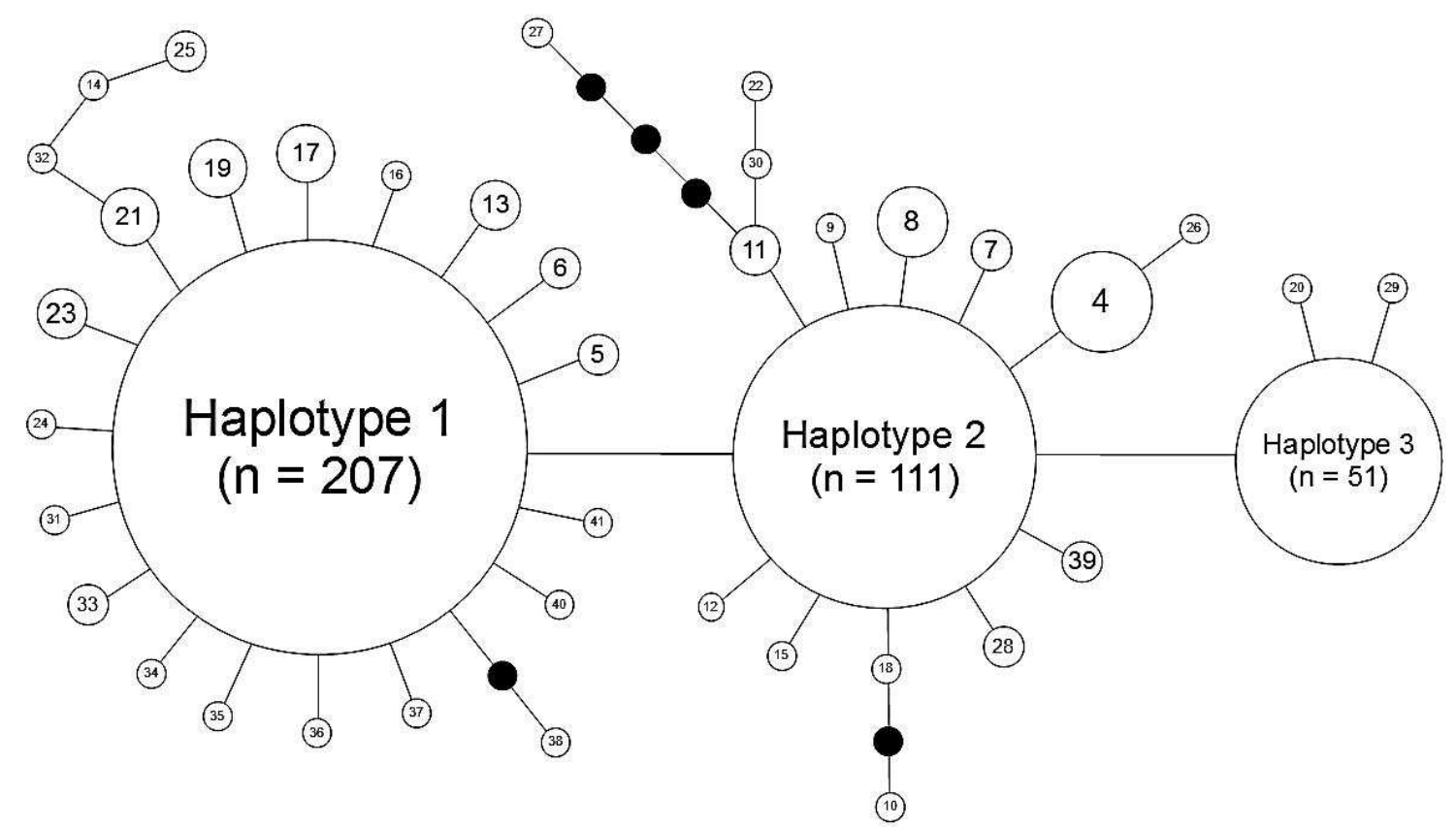

Figure 2: Haplotype Network of mtDNA sequences. Each line connecting two circles (regardless of length) is indicative of one nucleotide difference between haplotypes. For the major haplotypes $(1,2$, and 3), the number of individuals with that haplotype are indicated. The population size for each of the remaining haplotypes are indicated by circle size (For haplotype 4, n=12. For haplotype 8,n=6. The remaining haplotypes have 4 or less individuals in the population sampled). Black circles indicate missing steps to existing haplotypes.

Direct selection on this sequence is unlikely though, as nearly all of the sequence haplotypes (37 of 41) code for the same cytochrome c subunit I amino acid sequence. Selection could still be possible on a nearby, unsequenced section of mtDNA, leading to the increase in these identical DNA sequences through "genetic hitchhiking" (Barton 
2000, Kim \& Stephan 2000).

To test population substructure, pairwise $F_{s t}, F_{s t}$, and Jost's $D$ values were determined for each subpopulation pair (Tables 3, 4, and 5, respectively). Pairwise $F_{s t}$ (Weir \& Cockerham 1984) results revealed substructure in the overall population (Table 3). Iceberg Bay (BCIB), the northernmost sample of this dataset, has 9 of 16 pairwise $F_{s t}$ comparisons that are both high (between 0.13 and 0.31 ) and statistically significant ( $\mathrm{p}<$ 0.05). The average pairwise $F_{s t}$ for BCIB was 0.156 , compared to the overall pairwise $F_{s t}$ average of 0.028 across all subpopulations. Nisqually (WANQ) also has 9 of 16 comparisons that are statistically significant, but the $F_{s t}$ values are smaller than the pattern seen in BCIB (average $F_{s t}=0.044$ ), and Grays Harbor (WAGH) had 6 significant comparisons (average $F_{s t}=0.053$ ). The greatest pairwise $F_{s t}$ difference seen between all subpopulations was 0.309 , comparing BCIB to WAGH. Due to recent arguments over the validity of $F_{s t}$ or its relative, $G_{s t}$, as a comparator for population differentiation (Jost 2008, 2009, Ryman \& Leimar 2009, Heller \& Siegismund 2009), particularly in systems that are highly polyallelic, pairwise $F_{s t}{ }^{\prime}($ Hedrick 2005) and Jost's $D$ (Jost 2008) values are presented here for comparison (Tables 4 and 5, respectively). The same pattern of population differentiation with BCIB, WANQ and WAGH emerges in all three of these analyses. 


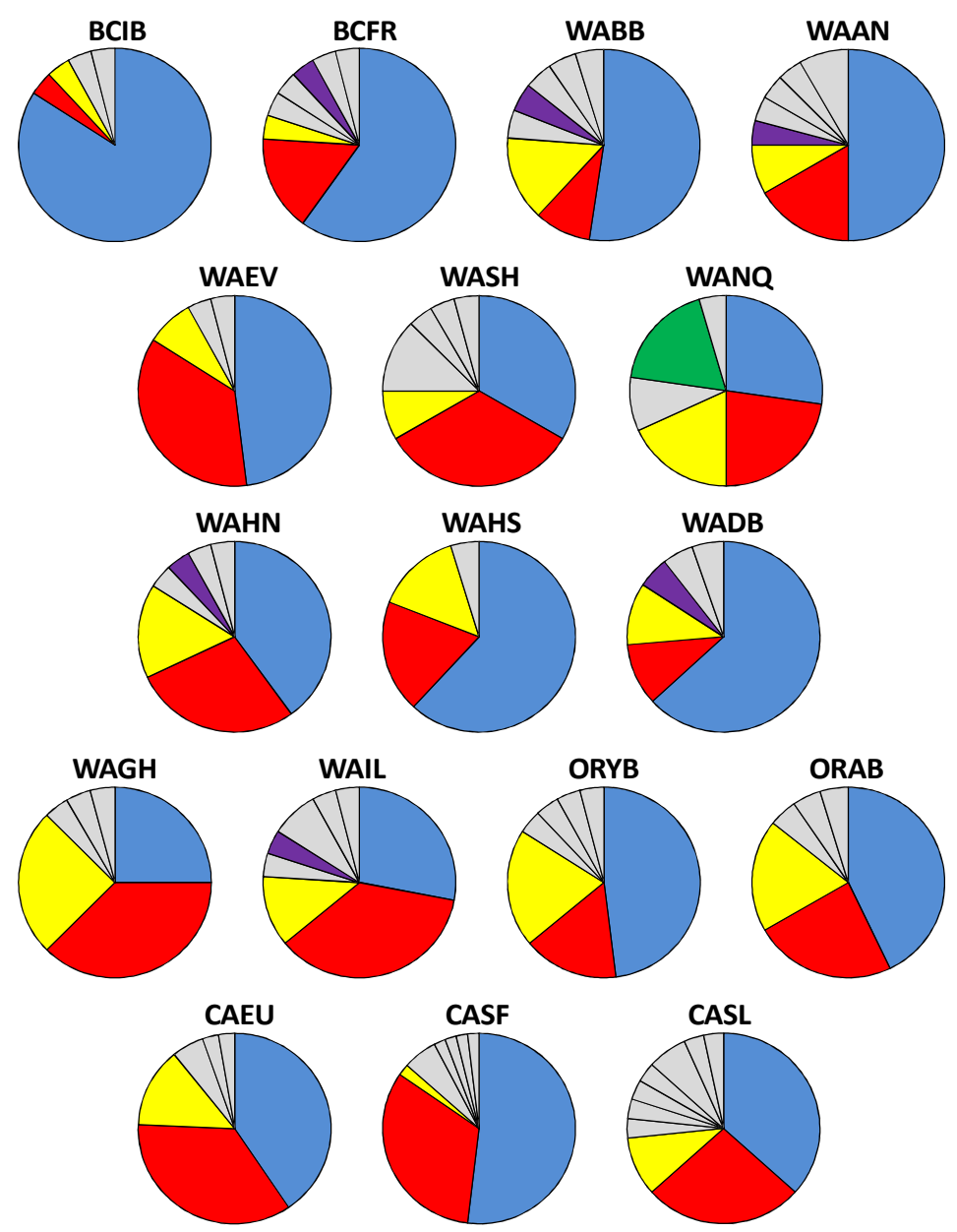

Figure 3: COI mtDNA frequencies for each sampled site, arrayed in a roughly northsouth orientation. Haplotype 1 is shown in blue, haplotype 2 shown in red, and haplotype 3 shown in yellow. Unspecified haplotypes are shown in grey. Haplotype 8 (purple) was rare but frequently present in northern samples. Haplotype 21 (green) was found only in the WANQ sample, and at high frequency (4 of 22 sequences, or $\sim 18 \%$ ). Note the increase in frequency of haplotype 1 in northern sites and the increase in haplotypes 2 and 3 in southern sites.

Site-specific frequencies of each major haplotype reveal a trend of increasing the frequency of both haplotypes 2 and 3 in southerly samples (Figure 3). Although haplotypes 1,2, and 3 are present in every sample, there is very little overlap of other sequence haplotypes. Haplotype 8 was found in low frequency within several northern sample sites (BCFR, WABB, WAAN, WAHN, WADB, and WAIL), but was absent in all 
southern sampling locations. Nearly every sampled location (with the exceptions of Iceberg Bay (BCIB), Northern Hood Canal (WAHN), and Alsea Bay (ORAB)) had at least one "singleton" site-specific mtDNA haplotype present. In Nisqually (WANQ), a site-specific haplotype was present at a high frequency, found in 4 out of 22 samples (shown in green, Figure 3).

\section{Microsatellites}

All microsatellite loci were found to be in Hardy-Weinberg equilibrium when tested using the entire population, though some loci were found to be out of equilibrium on a per-locus, per-site basis (Table 6). All HWE failures fit an excess heterozygosity model better than a heterozygote deficiency model, though none are statistically significant for either model. In addition, all loci were found to be in complete linkage disequilibrium using GENEPOP with the Markov chain method (10000 dememorizations, 20 batches, 5000 iterations per batch). Most loci had between 6 and 9 alleles in the entire sampled population, but Cma118 had 16 alleles and Cma108a had 17 alleles. These are quite highly polymorphic for a sample size of 10 individuals (20 alleles) per location. Rho st was determined for each locus at each sampling location (Table 7). Cma108a had a high Rhost in both the BCFR and WAAN locations (0.390 and 0.189 respectively), while the average across all pairwise comparisons was 0.030 . 
Table 3: Pairwise $F_{s t}$ values (Weir \& Cockerham 1984) for mtDNA COI sequences. Pairwise $F_{s t}$ values are below the diagonal, p-values for estimations are above the diagonal. Statistically significant pairwise $F_{s t}$ values are shown in bold and level of significance signified by $*(\mathrm{p}<0.05)$ or $* *(\mathrm{p}<0.01)$. Average value of all pairwise $F_{s t}$ values for each sampling site is shown in the bottom row.

\begin{tabular}{|c|c|c|c|c|c|c|c|c|c|c|c|c|c|c|c|c|c|}
\hline & BCIB & BCFR & WABB & WAAN & WAEV & WASH & WANQ & WAHN & WAHS & WADB & WAGH & WAIL & ORYB & ORAB & CAEU & CASF & CASL \\
\hline BCIB & & 0.539 & 0.414 & 0.111 & 0.021 & 0.004 & 0.000 & 0.022 & 0.182 & 0.495 & 0.000 & 0.001 & 0.068 & 0.051 & 0.001 & 0.027 & 0.019 \\
\hline BCFR & 0.047 & & 0.725 & 0.764 & 0.371 & 0.176 & 0.013 & 0.453 & 0.750 & 0.880 & 0.016 & 0.120 & 0.571 & 0.244 & 0.062 & 0.113 & 0.237 \\
\hline WABB & 0.077 & -0.017 & & 0.714 & 0.132 & 0.227 & 0.048 & 0.767 & 0.794 & 1.000 & 0.042 & 0.292 & 0.858 & 0.880 & 0.151 & 0.035 & 0.449 \\
\hline WAAN & 0.096 & -0.019 & -0.024 & & 0.271 & 0.122 & 0.151 & 0.533 & 0.627 & 0.780 & 0.040 & 0.216 & 0.383 & 0.441 & 0.070 & 0.029 & 0.309 \\
\hline WAEV & $0.172 *$ & 0.012 & 0.022 & -0.001 & & 0.318 & 0.030 & 0.651 & 0.493 & 0.214 & 0.156 & 0.361 & 0.237 & 0.441 & 0.521 & 0.408 & 0.662 \\
\hline WASH & $\begin{array}{c}0.227 \\
* *\end{array}$ & 0.048 & 0.032 & 0.018 & -0.009 & & 0.030 & 0.808 & 0.138 & 0.075 & 0.134 & 0.862 & 0.080 & 0.572 & 0.097 & 0.300 & 0.571 \\
\hline WANQ & $\begin{array}{c}0.255 \\
* * \\
* *\end{array}$ & $\mathbf{0 . 0 7 7} *$ & $0.040 *$ & 0.024 & $0.035 *$ & $0.011 *$ & & 0.092 & 0.042 & 0.034 & 0.077 & 0.062 & 0.063 & 0.110 & 0.014 & 0.000 & 0.059 \\
\hline WAHN & $0.178 *$ & 0.017 & -0.003 & -0.010 & -0.020 & -0.024 & 0.001 & & 0.665 & 0.517 & 0.534 & 0.968 & 0.656 & 0.990 & 0.438 & 0.290 & 0.838 \\
\hline WAHS & 0.055 & -0.026 & -0.024 & -0.019 & 0.002 & 0.046 & $0.067 *$ & 0.004 & & 0.808 & 0.078 & 0.141 & 0.945 & 0.726 & 0.336 & 0.177 & 0.560 \\
\hline WADB & 0.027 & -0.031 & -0.030 & -0.018 & 0.032 & 0.069 & $0.082 *$ & 0.024 & -0.035 & & 0.027 & 0.139 & 0.616 & 0.381 & 0.073 & 0.091 & 0.310 \\
\hline WAGH & $\begin{array}{c}0.309 \\
* * * \\
\end{array}$ & $0.109 *$ & $0.072 *$ & $0.057 *$ & 0.023 & -0.001 & 0.004 & -0.007 & 0.086 & $0.120 *$ & & 0.415 & 0.164 & 0.427 & 0.269 & 0.003 & 0.512 \\
\hline WAIL & $\begin{array}{c}\mathbf{0 . 2 6 3} \\
* * \\
\end{array}$ & 0.071 & 0.050 & 0.030 & 0.000 & -0.028 & 0.005 & -0.024 & 0.065 & 0.089 & -0.018 & & 0.121 & 0.608 & 0.178 & 0.094 & 0.533 \\
\hline ORYB & 0.119 & -0.002 & -0.029 & -0.018 & 0.006 & 0.020 & 0.020 & -0.017 & -0.020 & -0.010 & 0.034 & 0.029 & & 0.955 & 0.159 & 0.009 & 0.376 \\
\hline ORAB & 0.160 & 0.009 & -0.020 & -0.016 & -0.016 & -0.015 & 0.000 & -0.037 & -0.010 & 0.009 & -0.001 & -0.007 & -0.033 & & 0.381 & 0.286 & 0.808 \\
\hline CAEU & $\begin{array}{c}0.196 \\
* *\end{array}$ & 0.036 & 0.025 & 0.010 & -0.022 & -0.012 & $0.018 *$ & -0.023 & 0.021 & 0.051 & -0.002 & -0.011 & 0.006 & -0.019 & & 0.035 & 0.213 \\
\hline CASF & $0.131 *$ & 0.008 & $0.027 *$ & $0.006 *$ & -0.019 & 0.006 & $\begin{array}{c}\mathbf{0 . 0 6 8} \\
* * \\
\end{array}$ & 0.001 & 0.008 & 0.028 & $\begin{array}{c}\mathbf{0 . 0 6 8} \\
* * \\
\end{array}$ & 0.028 & $\begin{array}{c}\mathbf{0 . 0 2 5} \\
* * \\
\end{array}$ & 0.004 & $0.004 *$ & & 0.092 \\
\hline CASL & $0.178 *$ & 0.024 & 0.009 & -0.003 & -0.012 & -0.019 & 0.005 & -0.025 & 0.019 & 0.036 & 0.002 & -0.013 & -0.003 & -0.023 & -0.013 & 0.007 & \\
\hline Avg & 0.156 & 0.023 & 0.013 & 0.007 & 0.013 & 0.023 & 0.044 & 0.002 & 0.015 & 0.028 & 0.053 & 0.033 & 0.008 & -0.001 & 0.017 & 0.025 & 0.010 \\
\hline
\end{tabular}


Table 4: Pairwise $F_{s t}$ ' values (Hedrick 2005) for mtDNA COI sequences. Pairwise $F_{s t}$ ' values are below the diagonal, theoretical maximum $F_{s t}$ values are above the diagonal. Statistically significant pairwise $F_{s t}$ ' values are shown in bold and level of significance signified by $*(\mathrm{p}<0.05)$ or $* *(\mathrm{p}<0.01)$ - these values are carried over from the initial pairwise $F_{s t}$ calculations (table 3). Average value of all pairwise $F_{s t}$ ' values for each sampling site is shown in the bottom row.

\begin{tabular}{|c|c|c|c|c|c|c|c|c|c|c|c|c|c|c|c|c|c|}
\hline & ВCIB & BCFR & WABB & WAAN & WAEV & WASH & WANQ & WAHN & WAHS & WADB & WAGH & WAIL & ORYB & ORAB & CAEU & CASF & CASL \\
\hline BCIB & & 0.535 & 0.501 & 0.487 & 0.522 & 0.461 & 0.441 & 0.470 & 0.565 & 0.562 & 0.472 & 0.452 & 0.487 & 0.485 & 0.475 & 0.503 & 0.439 \\
\hline BCFR & 0.088 & & 0.327 & 0.320 & 0.357 & 0.294 & 0.270 & 0.305 & 0.391 & 0.383 & 0.305 & 0.28 & 0.322 & 0.311 & 0.328 & 0.370 & 0.282 \\
\hline WABB & 0.153 & -0.053 & & 0.274 & 0.313 & 0.249 & 0.222 & 0.260 & 0.348 & 0.338 & 0.260 & 0.241 & 0.277 & 0.264 & 0.287 & 0.333 & 0.238 \\
\hline WAAN & 0.198 & -0.059 & -0.088 & & 0.306 & 0.243 & 0.217 & 0.254 & 0.339 & 0.330 & 0.254 & 0.236 & 0.271 & 0.258 & 0.281 & 0.326 & 0.233 \\
\hline WAEV & $0.329 *$ & 0.034 & 0.070 & -0.004 & & 0.281 & 0.256 & 0.292 & 0.377 & 0.369 & 0.292 & 0.273 & 0.308 & 0.297 & 0.315 & 0.358 & 0.270 \\
\hline WASH & $\begin{array}{c}\mathbf{0 . 4 9 2} \\
* *\end{array}$ & 0.163 & 0.128 & 0.072 & -0.031 & & 0.191 & 0.229 & 0.313 & 0.304 & 0.228 & 0.210 & 0.246 & 0.232 & 0.257 & 0.303 & 0.208 \\
\hline WANQ & $0.578 *$ & $0.286 *$ & $0.178 *$ & 0.112 & $0.138 *$ & $0.059 *$ & & 0.203 & 0.288 & 0.278 & 0.202 & 0.184 & 0.220 & 0.206 & 0.233 & 0.281 & 0.183 \\
\hline WAHN & $0.379 *$ & 0.057 & -0.013 & -0.041 & -0.069 & -0.104 & 0.004 & & 0.324 & 0.315 & 0.240 & 0.222 & 0.257 & 0.244 & 0.267 & 0.313 & 0.220 \\
\hline WAHS & 0.097 & -0.067 & -0.068 & -0.056 & 0.006 & 0.147 & $0.231 *$ & 0.012 & & 0.406 & 0.324 & 0.305 & 0.341 & 0.331 & 0.346 & 0.388 & 0.300 \\
\hline WADB & 0.048 & -0.080 & -0.089 & -0.055 & 0.086 & 0.227 & $0.295 *$ & 0.075 & -0.086 & & 0.315 & 0.296 & 0.332 & 0.321 & 0.338 & 0.381 & 0.291 \\
\hline WAGH & $\begin{array}{c}\mathbf{0 . 6 5 5} \\
* * \\
\end{array}$ & $0.356 *$ & $0.277 *$ & $0.226 *$ & 0.077 & -0.005 & 0.019 & -0.030 & 0.266 & $0.380 *$ & & 0.221 & 0.256 & 0.243 & 0.267 & 0.313 & 0.219 \\
\hline WAIL & $\begin{array}{c}\mathbf{0 . 5 8 2} \\
* * * \\
\end{array}$ & 0.248 & 0.207 & 0.129 & -0.001 & -0.132 & 0.027 & -0.109 & 0.214 & 0.302 & -0.081 & & 0.238 & 0.225 & 0.250 & 0.297 & 0.202 \\
\hline ORYB & 0.244 & -0.007 & -0.103 & -0.065 & 0.020 & 0.081 & 0.090 & -0.065 & -0.058 & -0.029 & 0.133 & 0.120 & & 0.261 & 0.283 & 0.328 & 0.236 \\
\hline ORAB & 0.331 & 0.030 & -0.077 & -0.063 & -0.053 & -0.066 & 0.002 & -0.150 & -0.031 & 0.029 & -0.004 & -0.030 & -0.125 & & 0.272 & 0.318 & 0.223 \\
\hline CAEU & $\begin{array}{c}0.413 \\
* * \\
\end{array}$ & 0.110 & 0.089 & 0.036 & -0.070 & -0.046 & $0.079 *$ & -0.085 & 0.061 & 0.150 & -0.007 & -0.045 & 0.023 & -0.069 & & 0.333 & 0.247 \\
\hline CASF & $0.260 *$ & 0.022 & $\mathbf{0 . 0 8 0} *$ & $0.020 *$ & -0.052 & 0.021 & $\begin{array}{c}0.242 \\
* * * \\
\end{array}$ & 0.004 & 0.020 & 0.073 & $\begin{array}{c}0.216 \\
* * * \\
\end{array}$ & 0.094 & $\begin{array}{c}\mathbf{0 . 0 7 7} \\
* * \\
\end{array}$ & 0.013 & $0.012 *$ & & 0.292 \\
\hline CASL & $0.406 *$ & 0.085 & 0.036 & -0.013 & -0.045 & -0.093 & 0.025 & -0.112 & 0.062 & 0.122 & 0.008 & -0.065 & -0.012 & -0.105 & -0.054 & 0.023 & \\
\hline Avg & 0.328 & 0.076 & 0.045 & 0.022 & 0.027 & 0.057 & 0.148 & -0.015 & 0.047 & 0.090 & 0.155 & 0.091 & 0.020 & -0.023 & 0.037 & 0.070 & 0.017 \\
\hline
\end{tabular}


Table 5: Pairwise Jost's $D$ values (Jost 2008) for mtDNA sequences. Pairwise $D$ values are below the diagonal, distance (in $\mathrm{km}$ ) between sampling locations is above the diagonal. As no repeated subsampling takes place for this measurement, no statistical significance is assessed. Average value of all pairwise Jost's $D$ values for each sampling site is shown in the bottom row.

\begin{tabular}{|c|c|c|c|c|c|c|c|c|c|c|c|c|c|c|c|c|c|}
\hline & BCIB & BCFR & WABB & WAAN & WAEV & WASH & WANQ & WAHN & WAHS & WADB & WAGH & WAIL & ORYB & ORAB & CAEU & CASF & CASL \\
\hline BCIB & & 1176 & 1132 & 1092 & 1121 & 1120 & 1204 & 1140 & 1163 & 1031 & 1092 & 1172 & 1362 & 1390 & 1755 & 2225 & 2500 \\
\hline BCFR & 0.112 & & 44 & 84 & 201 & 200 & 284 & 220 & 243 & 145 & 456 & 536 & 726 & 754 & 1119 & 1589 & 1864 \\
\hline WABB & 0.160 & 0.092 & & 40 & 157 & 156 & 240 & 176 & 199 & 101 & 412 & 492 & 682 & 710 & 1075 & 1545 & 1820 \\
\hline WAAN & 0.184 & 0.083 & 0.092 & & 117 & 116 & 200 & 136 & 159 & 61 & 372 & 562 & 642 & 670 & 1035 & 1505 & 1780 \\
\hline WAEV & 0.250 & 0.124 & 0.170 & 0.120 & & 37 & 121 & 93 & 116 & 90 & 401 & 481 & 691 & 699 & 1064 & 1534 & 1809 \\
\hline WASH & 0.398 & 0.232 & 0.242 & 0.199 & 0.112 & & 84 & 92 & 115 & 89 & 400 & 480 & 690 & 698 & 1063 & 1533 & 1808 \\
\hline WANQ & 0.486 & 0.336 & 0.298 & 0.248 & 0.239 & 0.231 & & 176 & 199 & 173 & 484 & 564 & 774 & 782 & 1147 & 1617 & 1892 \\
\hline WAHN & 0.253 & 0.122 & 0.105 & 0.093 & 0.087 & 0.113 & 0.197 & & 23 & 109 & 420 & 500 & 710 & 718 & 1083 & 1553 & 1828 \\
\hline WAHS & 0.116 & 0.069 & 0.088 & 0.089 & 0.112 & 0.222 & 0.296 & 0.101 & & 132 & 443 & 523 & 733 & 741 & 1106 & 1576 & 1851 \\
\hline WADB & 0.099 & 0.070 & 0.086 & 0.099 & 0.166 & 0.286 & 0.352 & 0.138 & 0.071 & & 311 & 391 & 581 & 609 & 974 & 1444 & 1719 \\
\hline WAGH & 0.541 & 0.366 & 0.340 & 0.299 & 0.176 & 0.157 & 0.196 & 0.169 & 0.298 & 0.391 & & 80 & 270 & 298 & 663 & 1133 & 1408 \\
\hline WAIL & 0.481 & 0.293 & 0.298 & 0.239 & 0.131 & 0.084 & 0.213 & 0.123 & 0.269 & 0.341 & 0.109 & & 190 & 218 & 583 & 1053 & 1328 \\
\hline ORYB & 0.210 & 0.110 & 0.080 & 0.096 & 0.131 & 0.201 & 0.228 & 0.077 & 0.085 & 0.111 & 0.230 & 0.229 & & 28 & 393 & 863 & 1138 \\
\hline ORAB & 0.336 & 0.189 & 0.158 & 0.146 & 0.100 & 0.103 & 0.179 & 0.071 & 0.151 & 0.210 & 0.117 & 0.113 & 0.102 & & 365 & 835 & 1110 \\
\hline CAEU & 0.319 & 0.165 & 0.176 & 0.136 & 0.057 & 0.092 & 0.192 & 0.074 & 0.137 & 0.202 & 0.113 & 0.092 & 0.124 & 0.069 & & 470 & 745 \\
\hline CASF & 0.197 & 0.089 & 0.144 & 0.100 & 0.048 & 0.107 & 0.273 & 0.086 & 0.093 & 0.131 & 0.236 & 0.155 & 0.134 & 0.114 & 0.074 & & 275 \\
\hline CASL & 0.366 & 0.198 & 0.196 & 0.154 & 0.104 & 0.096 & 0.198 & 0.093 & 0.184 & 0.238 & 0.145 & 0.108 & 0.147 & 0.089 & 0.080 & 0.113 & \\
\hline Avg & 0.282 & 0.166 & 0.170 & 0.149 & 0.133 & 0.180 & 0.260 & 0.119 & 0.149 & 0.187 & 0.243 & 0.205 & 0.143 & 0.140 & 0.131 & 0.131 & 0.157 \\
\hline
\end{tabular}


Table 6: Summary statistics for all microsatellite loci. HWE: number of tests (out of 14) that fail Hardy-Weinberg equilibrium test; \# alleles: number of alleles found in the sampled population ( $\mathrm{n}=140,10$ individuals per sampling site); Ho: observed heterozygosity; $\mathrm{He}$ : expected heterozygosity; $R h o_{s t}$ : average $R h o_{s t}$ for each locus over all subpopulations.

\begin{tabular}{|c|c|c|c|c|c|}
\hline & HWE & \# alleles & Ho & He & Rho $_{\text {st }}$ \\
\hline Cma102 & 0 & 9 & 0.663 & 0.736 & 0.005 \\
\hline Cma103 & 1 & 8 & 0.743 & 0.721 & -0.009 \\
\hline Cma108a & 2 & 17 & 0.650 & 0.706 & 0.120 \\
\hline Cma108b & 1 & 9 & 0.789 & 0.735 & 0.015 \\
\hline Cma114 & 1 & 7 & 0.575 & 0.562 & -0.011 \\
\hline Cma117 & 0 & 6 & 0.672 & 0.579 & 0.038 \\
\hline Cma118 & 0 & 16 & 0.814 & 0.852 & -0.019 \\
\hline Overall & & & 0.701 & 0.699 & 0.044 \\
\hline
\end{tabular}

Pairwise $R h o_{s t}$ was calculated for each individual locus and for all loci combined, and pairwise Jost's $D$ was calculated for all loci combined (Table 8). The most differentiated subpopulation among all sampled locations was the Fraser River delta (BCFR), with an average pairwise $R h o_{s t}$ across all loci of 0.203 , nearly an order of magnitude higher than all other sampling locations and the overall average $R h o_{s t}$ of 0.030. This is likely driven entirely by the Cma108a allele frequencies at BCFR, and could be a product of the lower sample size to allelic variation ratio at this locus. This phenomenon was seen but not in as exaggerated a state in the pairwise Jost's $D$ calculations, where the average Jost's $D$ for BCFR was 0.057 as compared to the overall average Jost's $D$ of 0.008 . 
Table 7: Average $R h o_{s t}$ for each locus at each sampling location. Each value is the average of all pairwise $R h o_{s t}$ comparisons from that sample site to all other sample sites.

\begin{tabular}{|c|c|c|c|c|c|c|c|c|}
\hline & Cma102 & Cma103 & Cma108a & Cma108b & Cma114 & Cma117 & Cma118 & All loci \\
\hline BCIB & -0.020 & -0.018 & 0.019 & -0.013 & -0.030 & 0.047 & 0.026 & 0.012 \\
\hline BCFR & 0.040 & -0.016 & 0.390 & -0.009 & 0.000 & 0.075 & -0.020 & 0.203 \\
\hline WABB & -0.013 & 0.000 & 0.045 & 0.001 & -0.012 & 0.004 & 0.000 & 0.024 \\
\hline WAAN & -0.035 & -0.029 & 0.189 & -0.023 & 0.039 & -0.015 & -0.017 & 0.066 \\
\hline WAEV & -0.013 & 0.018 & 0.011 & 0.050 & 0.031 & 0.047 & -0.029 & 0.009 \\
\hline WASH & 0.008 & -0.025 & 0.026 & -0.001 & -0.021 & -0.003 & -0.021 & 0.014 \\
\hline WANQ & 0.031 & 0.001 & 0.006 & 0.001 & -0.024 & -0.001 & -0.035 & 0.011 \\
\hline WAHN & -0.026 & -0.014 & 0.007 & 0.010 & -0.033 & 0.048 & -0.037 & -0.006 \\
\hline WAHS & -0.020 & -0.021 & 0.014 & -0.016 & -0.042 & 0.057 & -0.018 & 0.004 \\
\hline WADB & -0.024 & 0.030 & 0.092 & 0.094 & 0.054 & -0.020 & -0.040 & 0.034 \\
\hline WAGH & -0.001 & -0.008 & 0.010 & 0.011 & -0.011 & 0.008 & -0.003 & 0.013 \\
\hline WAIL & 0.123 & -0.044 & 0.008 & -0.013 & -0.035 & 0.011 & -0.025 & 0.039 \\
\hline ORYB & -0.031 & -0.001 & 0.015 & 0.020 & -0.051 & -0.022 & -0.017 & -0.005 \\
\hline ORAB & -0.019 & -0.021 & 0.015 & 0.000 & -0.021 & 0.011 & -0.017 & 0.005 \\
\hline Avg & 0.000 & -0.011 & 0.061 & 0.008 & -0.011 & 0.018 & -0.018 & 0.030 \\
\hline
\end{tabular}

Test for Isolation by Distance

Pairwise $F_{s t}, F_{s t}$, and Jost's $D$ comparisons for all loci combined (mtDNA and microsatellites) showed an isolation by distance pattern of differentiation when analyzed via Mantel test in FSTAT ( $\mathrm{p}<0.001$, all cases), but only Jost's $D$ showed that same pattern when analyzed by Spearman rank coefficient in GenePop $(\mathrm{p}<0.001)$. When the two types of markers were separated and analyzed, mtDNA still showed an isolation by distance pattern by Mantel test only $(\mathrm{p}<0.02)$, but microsatellites did not support this. This pattern of isolation by distance may have been driven solely by the different mtDNA haplotype frequencies in the northernmost BCIB sample, as when that sample was removed from the analysis, no isolation by distance pattern could be seen in any combination of markers. This supported the findings that the BCIB site is different from 
the remaining sample locations, but that there is little to no regional structure among the Pacific coast Dungeness crab (California, Oregon, and Washington coasts). 
Table 8: Pairwise $R h o_{s t}$ and Jost's $D$ for all microsatellites combined. $R h o_{s t}$ values are below the diagonal, Jost's $D$ values are above the diagonal. Average values for both $R h o_{s t}$ and Jost's $D$ for each sampling site is shown in the bottom 2 rows.

\begin{tabular}{|c|c|c|c|c|c|c|c|c|c|c|c|c|c|c|}
\hline & BCIB & BCFR & WABB & WAAN & WAEV & WASH & WANQ & WAHN & WAHS & WADB & WAGH & WAIL & ORYB & ORAB \\
\hline BCIB & & 0.088 & -0.022 & 0.006 & -0.011 & -0.035 & -0.017 & -0.007 & -0.009 & -0.033 & 0.096 & -0.029 & 0.019 & -0.015 \\
\hline BCFR & 0.247 & & 0.103 & 0.008 & 0.032 & 0.107 & 0.055 & 0.000 & 0.049 & 0.096 & 0.038 & 0.062 & 0.026 & 0.069 \\
\hline WABB & -0.046 & 0.311 & & 0.079 & 0.039 & -0.004 & 0.023 & -0.020 & 0.008 & 0.036 & 0.050 & -0.015 & 0.085 & -0.004 \\
\hline WAAN & 0.082 & 0.040 & 0.136 & & 0.010 & 0.015 & 0.015 & 0.014 & 0.003 & 0.068 & 0.080 & -0.007 & 0.031 & 0.040 \\
\hline WAEV & -0.015 & 0.179 & 0.019 & 0.023 & & -0.036 & 0.002 & -0.072 & -0.006 & -0.008 & -0.001 & -0.033 & -0.027 & -0.049 \\
\hline WASH & -0.001 & 0.268 & 0.000 & 0.087 & -0.015 & & 0.011 & -0.031 & -0.038 & -0.011 & 0.031 & -0.062 & 0.025 & -0.054 \\
\hline WANQ & -0.042 & 0.209 & -0.038 & 0.065 & -0.004 & 0.011 & & -0.019 & 0.017 & -0.027 & 0.065 & -0.006 & 0.006 & 0.000 \\
\hline WAHN & -0.028 & 0.217 & -0.040 & 0.062 & -0.008 & -0.039 & -0.030 & & -0.071 & -0.037 & -0.027 & -0.049 & -0.010 & -0.049 \\
\hline WAHS & 0.003 & 0.132 & 0.010 & 0.015 & -0.007 & -0.005 & -0.020 & -0.044 & & 0.000 & 0.053 & -0.069 & 0.056 & -0.013 \\
\hline WADB & -0.009 & 0.303 & -0.029 & 0.154 & 0.031 & 0.006 & -0.003 & -0.033 & 0.020 & & 0.086 & -0.006 & 0.024 & 0.005 \\
\hline WAGH & -0.005 & 0.210 & 0.013 & 0.045 & -0.026 & -0.012 & -0.023 & -0.025 & -0.028 & 0.036 & & 0.019 & 0.022 & -0.018 \\
\hline WAIL & 0.043 & 0.243 & 0.049 & 0.083 & 0.014 & -0.008 & 0.064 & -0.017 & 0.017 & 0.014 & 0.054 & & -0.002 & -0.072 \\
\hline ORYB & -0.019 & 0.210 & -0.013 & 0.043 & -0.043 & -0.051 & -0.015 & -0.047 & -0.028 & -0.004 & -0.043 & -0.014 & & -0.008 \\
\hline ORAB & -0.038 & 0.278 & -0.041 & 0.095 & -0.026 & -0.046 & -0.016 & -0.047 & -0.004 & -0.014 & -0.014 & -0.001 & -0.051 & \\
\hline $\operatorname{Avg} R h o_{s t}$ & 0.012 & 0.203 & 0.024 & 0.066 & 0.009 & 0.014 & 0.011 & -0.006 & 0.004 & 0.034 & 0.013 & 0.039 & -0.005 & 0.005 \\
\hline $\operatorname{Avg} D$ & 0.002 & 0.057 & 0.027 & 0.028 & -0.012 & -0.006 & 0.010 & -0.029 & -0.002 & 0.015 & 0.038 & -0.021 & 0.019 & -0.013 \\
\hline
\end{tabular}




\section{$\underline{\text { Discussion }}$}

\section{Genetic Structure}

Genetic structure in Dungeness crab has been difficult to determine. Attempts have been made to assess subpopulation differentiation (Soule \& Tasto 1983, Beacham et al. 2008) with little substructure discovered. This is unsurprising, as the current thought is most marine organisms with a long pelagic larval duration (PLD) should show little neutral population substructure, though there are arguments against this notion (Palumbi 2003, Shanks et al. 2003, but see Weersing \& Toonen 2009). In order to maintain genetic connectivity through gene flow between subpopulations of a species, the dispersal distance must be greater than the distance between those subpopulations. Organisms with longer PLDs have the potential to disperse farther, as they are in the water column longer and thus experience the flow of currents for a longer period. Whether this potential is realized or if PLD and genetic distance are correlated at all is still under debate - many attempts have been made to generalize a pattern for PLD and genetic differentiation (Weersing \& Toonen 2009, Lowe \& Allendorf 2010, Selkoe et al. 2010, Selkoe \& Toonen 2011), although no clear pattern has yet to emerge.

In this study, we found little evidence of genetic structure over larger geographic distances in this species ( 2500 km). Isolation by Distance (IBD) models had a statistically significant fit only when including the most northerly population in Iceberg Bay. This pattern is due to both its geographic and genetic distance from the remainder of the sample population. When that subpopulation was removed from the analysis, no generalized IBD model was a statistical fit. In addition, the IBD models that did fit all 
were based on the mitochondrial DNA analyses; when microsatellites were analyzed alone, no IBD model was a statistical fit, even including the northern Iceberg Bay sample. It was, therefore, the different mtDNA haplotype frequencies in Iceberg Bay alone that drive all statistical power for signals of IBD.

Drift/migration equilibrium is different for mitochondrial alleles versus nuclear alleles (microsatellites) due to the varying nature by which these alleles are altered by drift. Each offspring has two separately inherited allele copies for any region in the autosomal genome but only one allele per mitochondrial genome. The effective population size of mitochondrial alleles can be further reduced by maternal inheritance patterns, if present in the study population. Genetic drift has a stronger influence driving variation in the mitochondrial genome as it has four-fold less overall material to buffer allele frequency changes within the population. If the species were limited in dispersal either by distance or ecological barriers, genetic drift would affect all subpopulations differentially. As the only subpopulations that show measurable signals of genetic drift are the Iceberg Bay (BCIB) and, to a smaller degree, the Nisqually (WANQ) and Grays Harbor (WAGH) samples, an explanation for this result is likely to be oceanographic in nature.

The splitting of the North Pacific current into the north-flowing, counterclockwise Alaskan current system and the south-flowing California Current system when it approaches the Washington coast (Dodimead et al. 1963) sets up the potential for the separation of subpopulations of marine organisms. Larvae released within the Alaskan gyre are likely to be transported northward, then seaward along the Aleutian Islands, and 
are very unlikely to travel southward and westward again to reach coastal Washington or more southern populations. Likewise, larvae released within the California / Davidson current system are very likely to mix either northwards or southward depending on the timing of both the release of eggs and the timing of the spring transition of the California current. The current is constrained, however, in transporting larvae northward past coastal Washington, as the strength of the Davidson current diminishes at these latitudes where it competes with the opposing North Pacific Gyre. This system sets up the potential for a soft larval dispersal barrier along the northern Washington coastline.

This structure of the current systems as they interact near the coast can explain the variability we saw in the data. The Iceberg Bay sample, the only one taken within the Alaska gyre system, was significantly different in mtDNA haplotype frequencies than all other samples, consistent with experiencing genetic drift that is not mitigated by migration. The Nisqually sample, at the extreme southern end of Puget Sound, was also significantly different in mtDNA allele frequencies than all other samples, and even included a high-frequency $(\sim 18 \%)$, private haplotype. Nisqually lies at the southernmost part of the Puget Sound in Washington, south of the Tacoma Narrows bridge which spans a pinchpoint in the drainage of the watershed system that is only $1.4 \mathrm{~km}$ wide. The potential for larval retention in this area is high, as a large amount of water is separated from the remainder of the Sound by this narrow channel, and previous studies of Dungeness crab (Beacham et al. 2008) have revealed that larval retention is possible in similar situations.

Lastly, we cannot ignore the possibility that natural selection has altered the 
mtDNA sequence haplotype frequencies through genetic hitchhiking on some beneficial local adaptation to the Iceberg Bay area. Multiple markers would have reduced the likelihood of mistaking either localized adaptation or genetic hitchhiking for neutral variation through genetic drift, but due to the highly polymorphic nature of the microsatellite markers used and the sample size taken at each population, no signals of differential variation were seen within these markers, leaving only the mtDNA as a reliable signal. Repeating this analysis with a larger sampling size per location would answer the question of neutral variation versus localized adaptation.

\section{Population Expansion After a Bottleneck}

Overall, there were a large number of sequence haplotypes for the mtDNA segment of cytochrome c oxidase subunit I used. Most of these ( 23 of 41 , or $~ 56 \%$ ) were "singletons," seen in only one individual within the entire 441samples. Only three of the haplotypes sequenced were in frequencies greater than 5\% within the population, and these haplotypes were found in all sampling locations. This excess of rare but effectively neutral mtDNA sequence haplotypes is also seen in the "star-phylogeny" (Figure 2). For mtDNA haplotypes, both Fu's $F s$ and Tajima's $D$ indices were highly negative and highly significant, indicating statistically that there is an excess of lowfrequency alleles in the population and suggesting a recent post-bottleneck population expansion (Tajima 1989, Fu 1997). Both of these models assume neutrality for the markers used, which is likely for this marker: out of the 41 haplotypes discovered, only 4 have non-synonymous mutations (haplotypes $31,38,39$, and 40 ), and these haplotypes 
are quite rare, describing only 1, 1, 2, and 1 individual each, respectively.

Range expansion northward after the relaxation of the last glacial period is a phenomenon typically thought of in terms of terrestrial organisms following the receding glaciers, but this pattern is also seen in marine organisms of the eastern Pacific ocean (Hellberg et al. 2001), where newly "uncovered" habitat opens up to population growth and expansion. Oceanographic conditions were greatly changed during the Pleistocene era, altering sea-surface temperatures, salinity, and other factors potentially important for species range limitations (Sancetta 1983). As the population grows into this expanded range, the DNA mutation rate does not change, but the absolute number of mutations in the population will increase in proportion to the population size. This will lead to a pattern of a few haplotypes of high frequency (historical population), and a large number of "new" low-frequency haplotypes or recent origin that are very closely related to those historical haplotypes. This is the pattern we see in our haplotype network (Figure 2), and further supports the findings of a recent post-bottleneck population expansion.

\section{Conclusions}

Dungeness crab show little population structure across large geographic scales in both mitochondrial DNA haplotype diversity and microsatellite DNA diversity. There is small DNA evidence that oceanographic patterns may separate the species into three regimes: the Alaska gyre, the Puget Sound, and the California Current system. To further resolve this question, a new study should take place that specifically targets the question of the existence of these three regimes. The current study effectively relied entirely on 
mitochondrial DNA evidence, as the resolving power of microsatellites used herein was diminished by the ratio of polymorphism to sampling size. In building on this work, a larger sampling size would be required to utilize the resolving power of multiple microsatellite loci in ensuring the neutrality of markers used.

Lastly, while Dungeness crab seem to fit the concept of species with long pelagic larval dispersal having little genetic structure across large geographic ranges, no strong pattern of association between larval duration and Isolation by Distance emerged. Attempting to generalize larval connectivity on a broader taxonomic scale through the use of one simple species-specific characteristic like pelagic larval duration is a valiant goal. But, as oceanographic conditions are complex and highly localized (both spatially and temporally) and each species has evolved specific reproductive adaptations for larval dispersal in response to that complexity (most having to do with the seemingly exquisite timing of reproduction, egg release, and larval duration), perhaps a species-by-species approach is more evolutionarily appropriate. 


\section{$\underline{\text { Literature Cited }}$}

Barton NH (2000) Genetic hitchhiking. Philosophical Transactions of the Royal Society of London Series B, Biological Sciences 355:1553-62

Beacham TD, Supernault KJ, Miller KM (2008) Population structure of Dungeness crab (Cancer magister) in British Columbia. Journal of Shellfish Research 27:901-906

Butler TH (1956) The distribution and abundance of early post-larval stages of the British Columbia commercial crab. Fish Res Board Can, Prog Rep Pacif Coast Stn 107:641-646

Cleaver FC (1949) Preliminary results of the coastal crab (Cancer magister) investigation. State of Washington, Department of Fisheries

Cowen RK, Sponaugle S (2009) Larval dispersal and marine population connectivity. Annual Review of Marine Science 1:443-466

Dinnel PA, Armstrong DA, McMillan RO (1993) Evidence for multiple recruitmentcohorts of Puget Sound Dungeness crab, Cancer magister. Marine Biology 115:5363

Dodimead AJ, Favorite F, Hirano T (1963) Review of Oceanography of the Subarctic Pacific Region. International North Pacific Fisheries Commission Bulletin 13:195

Excoffier L, Lischer HEL (2010) Arlequin suite ver 3.5: a new series of programs to perform population genetics analyses under Linux and Windows. Molecular Ecology Resources 10:564-7

Fu YX (1997) Statistical tests of neutrality of mutations against population growth, hitchhiking and background selection. Genetics 147:915-925

Fu YX, Li WH (1993) Statistical tests of neutrality of mutations. Genetics 133:693-709

Galindo HM, Pfeiffer-Herbert AS, McManus MA, Chao Y, Chai F, Palumbi SR (2010) Seascape genetics along a steep cline: using genetic patterns to test predictions of marine larval dispersal. Molecular Ecology 19:3692-707

Goudet J (2001) FSTAT, a program to estimate and test gene diversities and fixation indices (version 2.9.3). Available at http:// www2.unil.ch/popgen/softwares/fstat.htm

Harrison MK, Crespi BJ (1999) Phylogenetics of Cancer crabs (Crustacea: Decapoda: Brachyura). Molecular Phylogenetics and Evolution 12:186-99 
Hedrick PW (2005) A standardized genetic differentiation measure. Evolution 59:16331638

Hellberg ME (2009) Gene flow and isolation among populations of marine animals. Annual Review of Ecology, Evolution, and Systematics 40:291-310

Hellberg ME, Balch DP, Roy K (2001) Climate-driven range expansion and morphological evolution in a marine gastropod. Science 292:1707-1710

Heller R, Siegismund HR (2009) Relationship between three measures of genetic differentiation $\mathrm{G}_{\mathrm{ST}}, \mathrm{D}_{\mathrm{EST}}$ and $\mathrm{G}_{\mathrm{ST}}$ : how wrong have we been? Molecular Ecology 18:2080-2083

Huyer A, Kosro PM, Lentz SJ, Beardsley RC (1989) Poleward flow in the California Current system. In: Neshyba SJ, Mooers CNK, Smith RL (eds) Poleward Flows Along Eastern Ocean Boundaries. Springer-Verlag, New York, p 144-159

Jensen PC, Bentzen P (2004) Isolation and inheritance of microsatellite loci in the Dungeness crab (Brachyura $\square$ : Cancridae $\square$ : Cancer magister). Genome 47:325-331

Jost L (2008) Gst and its relatives do not measure differentiation. Molecular Ecology 17:4015-4026

Jost L (2009) D vs . G ST $\square$ : Response to Heller and Siegismund ( 2009 ) and Ryman and Leimar ( 2009 ). Molecular Ecology 18:2088-2091

Kaukinen KH, Supernault KJ, Miller KM (2004) Enrichment of tetranucleotide microsatellite loci from invertebrate species. Journal of Shellfish Research 23:621626

Kelly RP, Palumbi SR (2010) Genetic structure among 50 species of the northeastern Pacific rocky intertidal community. PLoS One 5:e8594

Kim Y, Stephan W (2000) Joint effects of genetic hitchhiking and background selection on neutral variation. Genetics 155:1415-1427

Lardy C (2005) Biogeographical genetic variation of the Dungeness crab (Cancer magister). Master's Thesis, San Jose State University

Librado P, Rozas J (2009) DnaSP v5: a software for comprehensive analysis of DNA polymorphism data. Bioinformatics 25:1451-1452

Lough RG (1976) Larval dynamics of the Dungeness crab, Cancer magister, off the central Oregon coast, 1970-71. Fishery Bulletin 74:353-376 
Lowe WH, Allendorf FW (2010) What can genetics tell us about population connectivity? Molecular Ecology 19:3038-51

Mcmillan RO, Armstrong DA, Dinnel PA (1995) Comparison of habitat use and growth rates of two northern Puget Sound cohorts of $0+$ age Dungeness crab, Cancer magister. Estuaries 18:390-398

Meirmans PG (2006) Using the AMOVA framework to estimate a standardized genetic differentiation measure. Evolution 60:2399-2402

Meirmans PG, Tienderen PH Van (2004) Genotype and Genodive: two programs for the analysis of genetic diversity of asexual organisms. Molecular Ecology Notes 4:792794

Palumbi SR (2003) Population genetics, demographic connectivity, and the design of marine reserves. Ecological Applications 13:S146-S158

Pinsky ML, Montes HR, Palumbi SR (2010) Using isolation by distance and effective density to estimate dispersal scales in anemonefish. Evolution 64:2688-700

Poole RL (1966) A description of laboratory-reared zoeae of Cancer magister Dana, and megalopae taken under natural conditions (Decapoda Brachyura). Crustaceana 11:83-97

Reeb CA, Avise JC (1990) A genetic discontinuity in a continuously distributed species: mitochondrial DNA in the American oyster, Crassostrea virginica. Genetics 124:397-406

Rohlf FJ (1973) Algorithm 76. Heirarchical clustering using the minimum spanning tree. The Computer Journal 16:93

Rousset F (2008) GENEPOP'007: a complete re-implementation of the GENEPOP software for Windows and Linux. Molecular Ecology Resources 8:103-6

Ryman N, Leimar O (2009) $\mathrm{G}_{\mathrm{ST}}$ is still a useful measure of genetic differentiation - a comment on Jost's D. Molecular Ecology 18:2084-2087

Sancetta C (1983) Effect of Pleistocene glaciation upon oceanographic characteristics of the North Pacific Ocean and Bering Sea. Deep Sea Research 30:851-869

Selkoe K, Toonen R (2011) Marine connectivity: a new look at pelagic larval duration and genetic metrics of dispersal. Marine Ecology Progress Series 436:291-305 
Selkoe K a, Watson JR, White C, Horin TB, Iacchei M, Mitarai S, Siegel D a, Gaines SD, Toonen RJ (2010) Taking the chaos out of genetic patchiness: seascape genetics reveals ecological and oceanographic drivers of genetic patterns in three temperate reef species. Molecular Ecology 19:3708-26

Shanks AL, Grantham BA, Carr MH (2003) Propagule dispersal distance and the size and spacing of marine reserves. Ecological Applications 13:S159-S169

Slatkin M (1973) Gene flow and selection in a cline. Genetics 75:733-756

Sotka EE, Wares JP, Barth J a, Grosberg RK, Palumbi SR (2004) Strong genetic clines and geographical variation in gene flow in the rocky intertidal barnacle Balanus glandula. Molecular ecology 13:2143-56

Soule M, Tasto RN (1983) Stock identification studies on the Dungeness crab, Cancer magister. In: Wild PW, Tasto RN (eds) Life history, environment, and mariculture studies of the Dungeness crab, Cancer magister, with emphasis on the central California fishery resource. California Department of Fish and Game, p 39

Sponaugle S, Cowen RK, Shanks A, Morgan SG, Leis JM, Pineda J, Boehlert GW, Kingsford MJ, Lindeman KC, Grimes C, Munro JL (2002) Predicting selfrecruitment in marine populations: biophysical correlates and mechanisms. Bulletin of Marine Science 70:341-375

Stone RP, O'Clair CE (2001) Seasonal movements and distribution of Dungeness crabs Cancer magister in a glacial southeastern Alaska estuary. Marine Ecology Progress Series 214:167-176

Tajima F (1989) Statistical method for testing the neutral mutation hypothesis by DNA polymorphism. Genetics 123:585-95

Tamura K, Peterson D, Peterson N, Stecher G, Nei M, Kumar S (2011) MEGA5: molecular evolutionary genetics analysis using maximum likelihood, evolutionary distance, and maximum parsimony methods. Molecular Biology and Evolution 28:2731-9

Taylor MS, Hellberg ME (2003) Genetic evidence for local retention of pelagic larvae in a Caribbean reef fish. Science 299:107-9

Toonen RJ, Locke M, Grosberg R (2003) Isolation and characterization of polymorphic microsatellite loci from the Dungeness crab Cancer magister. Molecular Ecology Notes 4:30-32 
Weersing K, Toonen R (2009) Population genetics, larval dispersal, and connectivity in marine systems. Marine Ecology Progress Series 393:1-12

Weir BS, Cockerham CC (1984) Estimating F-Statistics for the analysis of population structure. Evolution 38:1358-1370

Wild PW (1983) The influence of seawater temperature on spawning, egg development, and hatching success of the Dungeness crab, Cancer magister. In: Wild PW, Tasto RN (eds) Life history, environment, and mariculture studies of the Dungeness crab, Cancer magister, with emphasis on the central California fishery resource. California Department of Fish and Game, p 197

Wing SR, Botsford LW, Largier JL, Morgan LE (1995) Spatial structure of relaxation events and crab settlement in the northern California upwelling system. Marine Ecology Progress Series 128:199-211 